\begin{tabular}{c} 
Volume and Issues Obtainable at Center for Sustainability Research and Consultancy \\
Journal of Accounting and Finance in Emerging Economies \\
ISSN: 2519-0318 ISSN (E) 2518-8488 \\
Volume 6: Issue 1 March 2020 \\
CSRᄃ \\
Journal homepage: www.publishing.globalcsrc.org/jafee \\
\hline
\end{tabular}

\title{
Does Borrower's Personality Affects The Repayment of The Loan? A Study of Banking Sector of Pakistan
}

\author{
${ }^{1}$ Shahzadah Fahed Qureshi, ${ }^{2}$ Rashid Ahmad, ${ }^{3}$ Muhammad Saim Hashmi \\ ${ }^{1}$ Institute Of Social Sciences,Bahauddin Zakariya Univeristy, Multan, Pakistan: Fahadqureshi@Bzu.Edu.Pk \\ ${ }^{2}$ M.Phil Scholar (Public Administration), Bahauddin Zakariya Univeristy, Multan, Pakistan. \\ ${ }^{3}$ Mirpur University Of Science And Technology (MUST), Azad Jammu And Kashmir, Pakistan: \\ Msaimhashmi@Gmail.Com
}

\begin{tabular}{ll}
\hline \multicolumn{1}{c}{ ARTICLE DETAILS } & ABSTRACT \\
\hline History & The Continuing Global Increase In Economic Activities Is Increasing The \\
Available Online: March 2020 & Importance Of The Banking Sector As The Hub Of Such Activities. The \\
& Banking Sector Issue Loans To Individuals, Firms, And Government. \\
Various Factors Influence The Repayment Of These Loans. In This Study, \\
We Argue That The Personality Of The Borrower Affects The Repayment \\
Loan Repayment, Personality & Of The Loan. We Have Selected A Sample Of 500 Borrowers Of Five \\
Traits, Regular Borrower, & Major Banks In Pakistan By Using A Cluster Sampling Technique. We \\
Defaulter & Selected 250 (50\%) Regular Borrower And 250 (50\%) Defaulters. We \\
& Measured Borrower Personality Through A 44-Items Big Five Inventory \\
JEL Classification: & BFI) Questionnaire Similar To John \& Srivastava (1999). We Analyzed \\
H81, H89 & Data Using One-Way ANOVA And Regression. The Results Show \\
& Considerable Significant Differences Between The Personality Of Regular \\
& Borrowers And Defaulters On All Five Traits Of Personality, Which \\
& Reveals That The Borrower's Personality Affects The Repayment Of The \\
& Loan. The Defaulters Were High On Extroversion And Neuroticism \\
& Dimensions, While Regular Borrowers Were High On Agreeableness, \\
Conscientiousness, And Openness To Experience. The Results Also & Depict The Strong Effect Of Demographic Characteristics Such As \\
Income, Education, And Family Size On Loan Repayment. The Study \\
Suggests Banks Consider The Personality Traits Of The Borrower At The \\
Time Of Issuing Of Loan.
\end{tabular}

(C) 2020 The authors, under a Creative Commons Attribution-Non

OPEN ACCESS

Commercial 4.0

Corresponding author's email address: fahadqureshi@bzu.edu.pk

Recommended citation: Qureshi, S. F., Ahmad, R. \& Hashmi, M. S., (2020). Does Borrower's Personality Affects The Repayment of The Loan? A Study of Banking Sector of Pakistan. Journal of Accounting and Finance in Emerging Economies, 6 (1), 107-116

DOI: $10.26710 /$ Jafee.V6i1.1053

\section{Introduction}

Although Pakistan Is Considered As An Agricultural Country, However, More Than 50\% Of Its Income Is Generated From Service Sector. Banking Is A Sub-Sector Of The Service Sector And Regarded As A Vital Part Of All Sectors Of The Economy As It Offers Loans Which Are Crucial For The Functioning Of 
Agriculture As Well As Industrial Sectors. Banks Are The Pioneer Sector In Adopting Modern Technology In The Country. Till 2011, Near About 5200 Atms Were Working In Pakistan (PAF Air War College Karachi, 2011). Banking In Pakistan Is Generally Referred To As Commercial Banking As It Belongs The Most Substantial Part Of It. A Commercial Bank Is One Whose Primary Function Is To Generate Income By Accepting Deposits From The Public At A Low Rate Of Interest And Providing The Loan To The Persons And Organization In Need At A Relatively High Rate Of Interest. The Credit Or Loaning Is The Most Essential Function Of Commercial Banks. Credit Is A Crucial Factor In The Development Of The Country. It Provides Investment Opportunities And Decreases Poverty Level. It Is A Key Factor To Adopt Latest Technologies (Khandker \& Faruqee, 2003). Pakistan Belongs To Those Countries Where Rate Of Interest On Loans Is Very High And Hence The Default Rate Also. Decreasing The Default Rate Is The Main Issue Of Banking Sector All Over The World Especially In Pakistan. According To Hussain Et Al. (2014), Credit Risk Is Faced By About 82.2\% Banks Of Pakistani Southern Punjab Due To Farmer's Default.

Loan Repayment Refers To The Payment Of Loan And Its Interest On Time Without Any Delay. The Lender Should Not Provide Credit To Those People Who Do Not Repay The Loan On Time (Ha Q Et Al., 2009). The Lending Relationship Established Between Lender And Borrower After Issuing Of Credit. Strength And Weakness Of This Lending Relationship Is Dependent On The Competition Of The Financial Market. Increased Competition In The Financial Market Decrease The Probability To Meet Reward, And Resultantly This Increased Competition Leads To The Weak Level Of The Lending Relationship Among Lender And Borrower (Petersen, 1999). Increased Repayment Period Leads To More Risk Of Credit. Hence, The Repayment Period Is The Primary Determinant Of Loan Repayment Of The Borrower In Small-Scale Enterprises (Abreham, 2002). The Loan Amount Can Affect The Repayment Of Loan On Time. Determinants Of Loan Repayment At Borrower End Include Educational Level, Other Sources Of Income, And Repayment Period Etc. (Kibrom, 2010). Profitability, Interest Rate, Moral Hazards, And Economic Stability Are The Key Factors Which Are Influencing The Loan Repayment (Makorere, 2014).

Personality Can Be Differentiated And Described On The Base Of Possession Of Traits By A Person (Hollingworth, 1938). Features Of A Personality Describe The Behavior Of A Person. Behavior Of Man May Vary According To The Traits Kept By Him (Murray, 1938). Neuroticism Decreases Risk-Taking Behavior. (Rustichini Et Al., 2012). Psychological Interpretation Is One Of The Best Ways To Understand And Describe Personality (Hollingworth, 1938). The Brain Has Influence On The Thinking, Feeling And Behavioral Process Of A Person (Murray, 1938). Personality Factors Which Can Identify Saving And Borrowing Behavior Of A Person Are Emotional Stability, Autonomy, And Extroversion. Nyhus \& Webley (2001) Recognized That Personality Factors Which Are Essential For The Measurement Of A Particular Type Of Saving Behavior Are Agreeableness, Inflexibility, And Tough-Mindedness (Nyhus \& Webley, 2001). Neuroticism Decreases Risk-Taking Behavior (Rustichini Et Al., 2012).

In This Study, We Investigated The Relationship Between Borrower Personality And Loan Repayment In Pakistan, I.E., Which Type Of Borrower's Personality Leads To A Regular Compensation Of The Loan And Which One Leads To The Default Of The Loan. Financial Institutions Know The Relationship Between Borrower Personality And Loan Repayment Likely Yields Better. The Banks May Fill A Simple Questionnaire (Or Conduct A Short Interview) Before The Loan Issuing And May Have The Idea About The Possible Repayment (Or Default) Of The Loan In Advance. The Importance Of Low Default Rate Increased In The Increased Islamization Of The Banking Sector In Pakistan Where Banks Will Not In A Position To Merely Enhance Their Interest Rates With The Increase In Default Rate. Rauf \& Mahmood (2009) Insisted That Growth \& Financial Performance Of Microfinance Institutions Is Feeble In Pakistan And Continually Decreasing More And More Rather Than Investing More. According To Them, It Is Because Most Of The Borrowers Cause Bad Debts And Show Default Behavior At The Time Of 
Repayment And Profit Rate Of Such Institutions Is Very Low. Hence, The Study In The Direction To Reduce Defrault Rate Of Loans In Pakistan Is Vital.

\section{Literature Review}

Keeping In View The Importance Of The Credit Risk For A Financial Institution, The Plenty Of Research Work Is Available Related To Credit Especially Focusing On The Determinants Of Credit. The Early Research Work In This Direction Was Started In The First Half Of The Nineteenth Century. Chapman (1940) Identified That Fundamental Factors Which Can Affect Credit Risk Include Age Sex, Marital Status, Number Of Dependents, Ability Of The Borrower To Repay The Loan, Willingness To Repay The Loan, Moral Level, Financial And Professional Condition. Abreham (2002) Elaborated The Importance Of Repayment Period. According To Him, Credit Risk Increased With An Increase In The Period Of Repayment. He Concluded Repayment Period Is The Primary Determinant Of Loan Repayment Behavior Of Borrower In Small-Scale Enterprises. Feschijan (2008) Identified Accounting Information As Crucial Factor To Determine The Creditworthiness Of Loan Applicants. Kibrom (2010) Identified The Importance Of Educational Qualification, Other Sources Of Income, Purpose Of The Loan, And Repayment Period Of The Loan Etc For The Repayment Of Loan. Makorere (2014) Identified Profitability, Interest Rate, Economic Stability, And Moral Hazards As The Key Factors Which Are Influencing The Loan Repayment Behavior In Tanzania. Kim \& Devaney (2001) Identified Number Of Credit Cards, Interest Rate On Credit Card Loan, Credit Limit, Educational Level, Income Level, Assets Position, Positive Behavior Towards Credit, And Behind Schedule Payments As Positively Related To The Outstanding Credit Card Balance. Haile (2015) Identified That Income Level, Family Size, Attitude Towards Saving, Training Provided To The Customers And Experience Of The Customer Are Central Determinants Of Loan Repayment Performance; And Concluded That Default Behavior Of Customer Depends Upon These Elements Of Loan Repayment Performance.

However, The Studies Related To The Impact Of Personality On Loan Repayment Are Very Few And Conducted In Recent Times. Nyhus \& Webley (2001) Identified Personality Factors Identifying Saving And Borrowing Behavior Of A Person Are Autonomy, Emotional Stability And Extroversion Trait. Bertrand \& Morse (2011) Studied The Reasons For Cognitive Biases And Their Ability To Cause Financial Loss. On The Bases Of Correlation Analysis, They Suggested That Information From The Customer Related To Cognitive Biases Must Be Taken In Order To Regulate Borrowing And Hence To Avoid Financial Loss Ultimately. According To Cobb-Clark \& Schurer (2012), The Individuals Having More Moral Costa And Leas Naïve Showed A Low Level Of Default Behavior. By Analyzing Data Collected From 105 Bank Borrowers, Ogeisia Et Al., (2014) Concluded That There Is A Positive Relationship Between The Character Of Customer And Repayment Of The Loan. The Character Of The Customer Is The Main Factor In Finding Loan Repayment Attitude. Their Study Suggests That The Lender Should Check The Character Of The Borrower, In Order To Ensure Repayment Of The Loan. Hunt \& Wilson (2016) Explored The Possible Impact Of Personality Characteristics Of Small Loans Borrowers On The Effectiveness Of Australian Loan Regulations. They Identified Three Personality Traits Likely To Be Most Relevant To Borrower Behavior, I.E., Risk Tolerance, Optimism, And SelfControl. Other Characteristics Which Can Impact On Debt Behavior Are Financial Literacy And Irrational Behavior.

The Personality Is One Of The Most Critical Determinants Of Loan Repayment. However, The Studies Related To The Impact Of Personality On Loan Repayment Are Very Few, Especially In The Pakistani And South Asian Environment, Having The Different Culture From The Other Parts Of The World. The Present Study Is Aiming To Fill This Gap. 


\section{Research Methodology}

The Population Of The Study Was The Borrowers Of The Banking Sector Of Pakistan. We Used Cluster Sampling Technique Following Nguta \& Guyo (2013). We Divided Borrowers Into Two Groups (I.E., Good Borrowers, And Bad Borrowers Or Defaulters) Similar To Haile (2015) Who Selected 120 Household Borrowers To Find Determinants Of Loan Repayment Performance Of Microfinance Institutions Including 50\% Defaulters And 50\% Non-Defaulters. We Requested Five Major Banks (I.E., NBP, UBL, ZTBL, Meezan Bank Ltd, And HBL) Of The Country To Provide The List Of 250 Good Borrowers And 250 Defaulters. Following Kibrom (2010) To Select Borrowers From One Specific Region (I.E., North Region) Of Ethiopia To Find The Determinants Of The Successful Loan Repayment, We Selected Borrowers From One Specific Region Of Pakistan (I.E., Southern Punjab).

We Conducted A Face-To-Face Structured Interview With The Respondents. We Grouped Interview Questions Into Three Sections. The First Section Is Related To Demographic Information. This Section Includes The Ability Of The Borrower To Repay The Loan, Age, Sex, Marital Status, And The Number Of Persons Depending On The Borrower As These Are The Are Basic Factors Which Can Affect Credit Risk (Chapman, 1940). The Second Section Is Related To Personality, And The Third Section Is Related To Loan Repayment. We Used 44 Items Big Five Inventory (BFI) Questionnaire To Measure Personality Similar To John \& Srivastava (1999) And Adopted The Loan Repayment Behavior Section From Kibrom (2010). We Modified Interview Questions And Made Few Additions (And Deletions) To Make The Tool Suitable For Collection Of Data From The Pakistani Borrowers.

To Exclude Bias, Interviewers Contacted All Borrowers In Face-To-Face Meetings. Interviewers Established A Good Report At The Start Of The Interview, In Which, The Borrower Was Convinced That The Information Is Only For The Study-Related Purpose And His Name And Other Information Will Be Kept Strictly Confidential.

We Used Cronbach Alpha Technique To Ensure The Validity And Reliability Of 44 Items Big Five Inventory (BFI) Questionnaire Scale. We Performed A Descriptive Analysis Of The Demographic Characteristics Of The Borrowers. We Used Correlation Analysis Following Bertrand \& Morse (2011) To Check The Association Between Repayment And Personality Traits. To Know The Mean Differences Of Regular Borrowers And Defaulters On Personality Traits, We Compared Means Of Borrowers' Personality And Their Loan Repayment Following Cole Et Al., (2015). We Used One Way ANOVA To Check The Difference Between Two Groups Of Borrowers, I.E., Regular Borrowers And Defaulters On All Personality Traits. In The End, To Check The Direction And Intensity Of The Impact, We Used Regression Analysis.

\section{Results and Discussion}

The Results Of The Demographic Profile Are Given In Table No. 1. The Results Show That People Having Young Age Are Mostly Defaulters While People Having Relatively Elder Ages Are Regular Borrowers. 194 (77.6\%) Defaulters Have Age Less Than 35 Compared To Only 12 (4.8\%) Regular Borrowers Of The Same Age Group. The Gender And Marital Status Have No Significant Effect On Repayment Behavior. Education Level Has A Significant Relationship With The Repayment Behavior Of Loan. Regular Borrowers Are Well-Educated People While Defaulters Are Mostly Less Educated Or Illiterate People. 224 (89.6\%) Defaulters Are Either Illiterate Or Having The Primary Education While 234 (93.6\%) Regular Borrowers Were Having The Secondary And Tertiary Education. Family Size Is One Other Vital Factor In The Loan Repayment. People Having Large Family Size Are Mostly Defaulters While People With Small Family Size Are Regular Borrowers. 209 (83.6\%) Regular Borrowers Have A Family Size Of 2-5 While 235 (94\%) Defaulters Have A Family Size Of 6-15. 
Table No. 1: Demographic Profile Of The Borrowers

\begin{tabular}{|c|c|c|c|c|c|c|c|}
\hline & & \multicolumn{2}{|c|}{ Regular Borrower } & \multicolumn{2}{|l|}{\begin{tabular}{|l|} 
Defaulter \\
\end{tabular}} & \multicolumn{2}{|l|}{ Overall } \\
\hline & & Frequency & $\%$ Age & Frequency & $\%$ Age & Frequency & $\%$ Age \\
\hline \multicolumn{8}{|l|}{ Age } \\
\hline & 25 And Below & 1 & 0.4 & 0 & 0 & 1 & 0.2 \\
\hline & $26-30$ & 5 & 2 & 86 & 34.4 & 91 & 18.2 \\
\hline & $31-35$ & 6 & 2.4 & 108 & 43.2 & 114 & 22.8 \\
\hline & $36-40$ & 42 & 16.8 & 37 & 14.8 & 79 & 15.8 \\
\hline & $41-45$ & 87 & 34.8 & 6 & 2.4 & 93 & 18.6 \\
\hline & $46-50$ & 64 & 25.6 & 8 & 3.2 & 72 & 14.4 \\
\hline & 51 And Above & 45 & 18 & 5 & 2 & 50 & 10 \\
\hline & Total & 250 & 100 & 250 & 100 & 500 & 100 \\
\hline \multicolumn{8}{|l|}{ Gender } \\
\hline & Male & 250 & 100 & 250 & 100 & 500 & 100 \\
\hline & Total & 250 & 100 & 250 & 100 & 500 & 100 \\
\hline \multicolumn{8}{|c|}{ Marital Status } \\
\hline & Single & 3 & 1.2 & 0 & 0 & 3 & 0.6 \\
\hline & Married & 232 & 92.8 & 229 & 91.6 & 461 & 92.2 \\
\hline & Divorced & 6 & 2.4 & 8 & 3.2 & 14 & 2.8 \\
\hline & Wife Died & 9 & 3.6 & 13 & 5.2 & 22 & 4.4 \\
\hline & Total & 250 & 100 & 250 & 100 & 500 & 100 \\
\hline \multicolumn{8}{|c|}{ Education Level } \\
\hline & Illiterate & 2 & 0.8 & 117 & 46.8 & 119 & 23.8 \\
\hline & $\begin{array}{l}\text { Primary } \\
\text { Education }\end{array}$ & 14 & 5.6 & 107 & 42.8 & 121 & 24.2 \\
\hline & $\begin{array}{l}\text { Secondary } \\
\text { Education }\end{array}$ & 103 & 41.2 & 21 & 8.4 & 124 & 24.8 \\
\hline & $\begin{array}{l}\text { Tertiary } \\
\text { Education }\end{array}$ & 131 & 52.4 & 5 & 2 & 136 & 27.2 \\
\hline & Total & 250 & 100 & 250 & 100 & 500 & 100 \\
\hline \multicolumn{8}{|c|}{ Family Size } \\
\hline & $2-5$ & 209 & 83.6 & 15 & 6 & 224 & 44.8 \\
\hline & $6-10$ & 41 & 16.4 & 165 & 66 & 206 & 41.2 \\
\hline & $11-15$ & 0 & 0 & 70 & 28 & 70 & 14 \\
\hline & Total & 250 & 100 & 250 & 100 & 500 & 100 \\
\hline
\end{tabular}

We Adopted The Questionnaire Used In Previous Studies, Did Necessary Modifications According To The Changes Of Situation And Environment, And Tested For Reliability. The Reliability Statistics Of Personality Traits Are Given In Table No. 2. The Value Of Chronbatch Alpha Is More Than 0.7 For Items Of Each Trait Which Shows That Our Scale To Measure These Traits Is Reliable. 
Table No. 2: Reliability Statistics Of Personality Traits

\begin{tabular}{|c|c|c|}
\hline Personality Trait & $\begin{array}{l}\mathrm{N} \text { Of } \\
\text { Items }\end{array}$ & $\begin{array}{l}\text { Cronbatch } \\
\text { Alpha }\end{array}$ \\
\hline Extroversion & 5 & 0.828 \\
\hline Agreeableness & 9 & 0.971 \\
\hline Conscientiousness & 9 & 0.966 \\
\hline Neuroticism & 8 & 0.7 \\
\hline $\begin{array}{ll}\text { Openness } & \text { To } \\
\text { Experience } & \\
\end{array}$ & 9 & 0.765 \\
\hline
\end{tabular}

According To Table No. 3, There Exists A Significantly Strong Correlation Among All Personality Traits And Loan Repayment. This Relationship Is Positive For The Association Of Loan Repayment With Three Personality Traits, I.E., Conscientiousness, Agreeableness, And Openness To Experience. It Shows That Loan Repayment Increases With The Increase In Conscientiousness, Agreeableness, And Openness To Experience (And Vice Versa). On The Contrary, There Exists A Negative Relationship For The Association Of Loan Repayment With Two Remaining Personality Traits, I.E., Extroversion And Neuroticism. It Shows That Loan Repayment Decreases And The Matter Go Towards Default Side With The Increase In Extroversion And Neuroticism (And Vice Versa).

Table No. 3: Correlation Among Personality Traits And Loan Repayment (N=500)

\begin{tabular}{|l|l|l|l|l|l|l|}
\hline & $\begin{array}{l}\text { Extroversio } \\
\mathrm{n}\end{array}$ & $\begin{array}{l}\text { Agreeablenes } \\
\mathrm{s}\end{array}$ & $\begin{array}{l}\text { Conscientious } \\
\text { ness }\end{array}$ & Neuroticism & $\begin{array}{l}\text { Openness } \\
\text { To } \\
\text { Experience }\end{array}$ & $\begin{array}{l}\text { Repayme } \\
\text { nt } \\
\text { Behavior }\end{array}$ \\
\hline Extroversion & 1 & & & & & \\
\hline Agreeableness & $.943^{* *}$ & 1 & & & & \\
\hline Conscientiousness & $.945^{* *}$ & $-.977^{* *}$ & 1 & & & \\
\hline Neuroticism To & $-.927^{* *}$ & $.949^{* *}$ & $.951^{* *}$ & 1 & & \\
\hline $\begin{array}{l}\text { Openness } \\
\text { Experience }\end{array}$ & $.919 * *$ & $-.952^{* *}$ & $-.952^{* *}$ & $.921^{* *}$ & 1 & 1 \\
\hline $\begin{array}{l}\text { Repayment } \\
\text { Behavior }\end{array}$ & $-.926^{* *}$ & $.956^{* *}$ & $.961^{* *}$ & $-.943^{* *}$ & $.920^{* *}$ & 1 \\
\hline
\end{tabular}

**. Correlation Is Significant At The 0.01 Level (2-Tailed).

Table No. 4 Shows The Comparison Of Mean And Standard Deviation For Both Regular Borrowers And Defaulters. The Findings Depict That There Exists A Considerable Difference Between Both Groups Of Borrowers. The Mean Of Regular Borrowers Is 2.7800 For Extroversion (4.09 For Defaulters), 4.1609 For Agreeableness (2.19 For Defaulters), 4.2071 For Conscientiousness (2.13 For Defaulters), 2.39 For Neuroticism (3.51 For Defaulters) And 3.62 For Openness To Experience (2.49 For Defaulters).

Findings Show That Borrowers Having Low Extroversion Means Are Mostly Regular While Respondents Who Have High Extroversion Mean Are Mostly Defaulters. The Borrowers Having High Agreeableness Are Mostly Regular While Who Have Low Agreeableness Are Mostly Defaulters. The Borrowers Having High Conscientiousness Are Mostly Regular And Borrowers Having Low Conscientiousness Are Mostly Defaulters. The Borrowers Having High Neuroticism Are Mostly Defaulters And The Borrowers Having Low Neuroticism Are Mostly Regular. The Borrowers Having A High Openness To Experience Are Mostly Regular And Borrowers Having A Low Openness To Experience Trait Are Mostly Defaulters. So, In Short, It Has Resulted That The Borrowers Having Less Extroversion, High Conscientiousness, High 
Agreeableness, Low Neuroticism And High Openness To Experience Traits Are Mostly Regular And The Borrowers Having Extroversion, Low Conscientiousness, Low Agreeableness, High Neuroticism, And Low Openness To Experience Traits Are Mostly Defaulters.

All The Values Of ANOVA Are Highly Significant Which Proves That Both Groups Of Borrowers', I.E., Regular Borrowers And Defaulters Differ Significantly On All Personality Traits.

Table No. 4: Comparison Of Mean, Standard Deviation And One Way ANOVA

\begin{tabular}{|c|c|c|c|c|c|c|c|c|c|}
\hline Personality Trait & $\begin{array}{l}\text { Borrower } \\
\text { Category }\end{array}$ & $\begin{array}{l}\text { Mean } \\
\text { Valus }\end{array}$ & \begin{tabular}{|l|} 
SD \\
Value
\end{tabular} & Variance & $\begin{array}{l}\text { Sum Of } \\
\text { Squares }\end{array}$ & Df & \begin{tabular}{|l} 
Mean \\
Square \\
\end{tabular} & $\mathrm{F}$ & Sig. \\
\hline \multirow[t]{3}{*}{ Extroversion } & $\begin{array}{l}\text { Regular } \\
\text { Borrower }\end{array}$ & 2.78 & 0.29 & $\begin{array}{l}\text { Between } \\
\text { Groups }\end{array}$ & 215.430 & 1 & 215.430 & 2991 & 0.000 \\
\hline & Defaulter & 4.09 & 0.23 & Within Groups & 35.867 & 498 & 0.072 & & \\
\hline & Overall & 3.43 & 0.70 & Total & 251.298 & 499 & & & \\
\hline \multirow[t]{3}{*}{ Agreeableness } & $\begin{array}{l}\text { Regular } \\
\text { Borrower }\end{array}$ & 4.16 & 0.35 & $\begin{array}{l}\text { Between } \\
\text { Groups }\end{array}$ & 485.222 & 1 & 485.222 & 5280 & 0.000 \\
\hline & Defaulter & 2.19 & 0.24 & Within Groups & 45.761 & 498 & 0.092 & & \\
\hline & Overall & 3.17 & 1.03 & Total & 530.983 & 499 & & & \\
\hline \multirow[t]{3}{*}{ Conscientiousness } & $\begin{array}{l}\text { Regular } \\
\text { Borrower }\end{array}$ & 4.2 & 0.32 & $\begin{array}{l}\text { Between } \\
\text { Groups }\end{array}$ & 535.498 & 1 & 535.498 & 6077 & 0.000 \\
\hline & Defaulter & 2.13 & 0.26 & Within Groups & 43.882 & 498 & 0.088 & & \\
\hline & Overall & 3.17 & 1.07 & Total & 579.380 & 499 & & & \\
\hline \multirow[t]{3}{*}{ Neuroticism } & $\begin{array}{l}\text { Regular } \\
\text { Borrower }\end{array}$ & 2.39 & 0.21 & $\begin{array}{l}\text { Between } \\
\text { Groups }\end{array}$ & 158.203 & 1 & 158.203 & 399 & 0.000 \\
\hline & Defaulter & 3.51 & 0.17 & Within Groups & 19.731 & 498 & 0.040 & & \\
\hline & Overall & 2.95 & 0.59 & Total & 177.934 & 499 & & & \\
\hline \multirow[t]{3}{*}{\begin{tabular}{|l} 
Openness \\
Experience \\
\end{tabular}} & $\begin{array}{l}\text { Regular } \\
\text { Borrower }\end{array}$ & 3.62 & 0.26 & $\begin{array}{l}\text { Between } \\
\text { Groups }\end{array}$ & 160.934 & 1 & 160.934 & 273 & 0.000 \\
\hline & Defaulter & 2.49 & 0.22 & Within Groups & 29.313 & 498 & 0.059 & & \\
\hline & Overall & 3.06 & 0.61 & Total & 190.246 & 499 & & & \\
\hline
\end{tabular}

Mean Values: 1= Strongly Disagree, $2=$ Disagree, $3=$ Neutral, $4=$ Agree, And $5=$ Strongly Agree

Table No. 5 Shows The Regression Results Of The Model. We Took Loan Repayment As A Dependent Variable While Personality Traits As Independent Variables. The Value Of R Square Is 0.936 Which Shows That Independent Variables Explain 93.6\% Variations In The Dependent Variable. The Beta Values Of Extroversion And Openness To Experience Are Not Significant While The Beta Values Of The Remaining Three Traits Are Highly Significant. The Beta Value Of Neuroticism Is Negative Which Depicts That Increase In Neuroticism Trait Decrease The Loan Repayment. On The Contrary, The Beta Values Of Conscientiousness And Agreeableness Are Positive. These Positive Values Describe That Increase In Conscientiousness And Agreeableness Increase The Loan Repayment.

Table No. 5: Regression Results (Dependent Variable = Loan Repayment)

\begin{tabular}{|l|l|l|l|l|l|}
\hline Variables & B & $\begin{array}{l}\text { Std. } \\
\text { Error }\end{array}$ & Beta & T Value & P Value \\
\hline$($ Constant $)$ & 1.714 & 0.199 & & 8.626 & 0.000 \\
\hline Extroversion & -0.045 & 0.026 & -0.064 & 1.716 & 0.087 \\
\hline
\end{tabular}




\begin{tabular}{|l|l|l|l|l|l|}
\hline Agreeableness & 0.132 & 0.029 & 0.271 & -4.565 & 0.000 \\
\hline Conscientiousness & 0.221 & 0.028 & 0.477 & -7.801 & 0.000 \\
\hline Neuroticism & -0.197 & 0.033 & -0.235 & 5.963 & 0.000 \\
\hline Openness To Experience & -0.055 & 0.032 & -0.068 & 1.714 & 0.087 \\
\hline
\end{tabular}

$\mathrm{R}=0.968, \mathrm{R}$ Square $=0.936, \mathrm{~F}=1.452$

\section{Conclusion}

There Exists A Significant Relationship Between Borrowers Personality And Loan Repayment. Young Borrowers Are Mostly Defaulters While Elder Age Borrowers Are Usually Regular Borrowers. Less Educated Borrowers Are Usually Defaulters While Well-Educated Borrowers Are Usually Regular Borrowers. Borrowers Having Low Family Size Are Usually Regualr Borrowers While Borrowers Having More Family Members Are Mostly Defaulters. There Is A Negative Relationship Between Extroversion Trait And Loan Repayment, Positive Relationship Between Agreeableness Trait And Loan Repayment, Positive Relationship Between Conscientiousness Trait And Loan Repayment, Negative Relationship Between Neuroticism Trait And Loan Repayment And Positive Relationship Between Openness To Experience Trait And Loan Repayment. The Borrowers Who Have Less Extroversion, High Conscientiousness, High Agreeableness, Low Neuroticism And High Openness To Experience Traits Are Mostly Regular While The Borrowers Having High Extroversion, Low Conscientiousness, Low Agreeableness, High Neuroticism, And Low Openness To Experience Traits Are Mostly Defaulters.

\section{References}

Abreham, G. (2002). Loan Repayment And Its Determinants In Small Scale Enterprises Financing In Ethiopia: Case Of Private Borrowers Around Zeway Area. Aau.

Bertrand, M., \& Morse, A. (2011). Information Disclosure, Cognitive Biases, And Payday Borrowing. The Journal Of Finance, 66(6), 1865-1893.

Chapman, J. M. (1940). Factors Affecting Credit Risk In Personal Lending Commercial Banks And Consumer Instalment Credit (Pp. 109-139): NBER.

Cobb-Clark, D. A., \& Schurer, S. (2012). The Stability Of Big-Five Personality Traits. Economics Letters, 115(1), 11-15.

Cole, S., Kanz, M., \& Klapper, L. (2015). Incentivizing Calculated Risk-Taking: Evidence From An Experiment With Commercial Bank Loan Officers. The Journal Of Finance, 70(2), 537-575.

Feschijan, D. (2008). Analysis Of The Creditworthiness Of Bank Loan Applicants. Journal Economics And Organization, 5(3), 273-280.

Haile, F. (2015). Determinants Of Loan Repayment Performance: Case Study Of Harari Microfinance Institutions. Journal Of Agricultural Extension And Rural Development, 7(2), 56-64.

Haq, M. F., Akmal, M., Shafique, B., Abbasi, M. U., \& Chaudhry, M. S. (2009). Towards Achieving Social And Financial Sustainability: A Study On The Performance Of Microfinance In Pakistan. International Labor Organization; State Bank Of Pakistan, 7.

Hollingworth, H. (1938). Review Of Personality: A Psychological Interpretation.

Hunt, K. H. M., \& Wilson, T. (2016). The Impact Of Borrower Characteristics On The Effectiveness Of Small Loan Regulation.

Hussain, T., Aslam, Z., Aslam, S., Latif, M., \& Ahmad, S. Credit Risk Management Practices Used By Banks In Agricultural Finance: A Case Study Of Pakistan.

John, O. P., \&Srivastava, S. (1999). The Big Five Trait Taxonomy: History, Measurement, And Theoretical Perspectives. Handbook Of Personality: Theory And Research, 2(1999), 102-138.

Khandker, S. R., \& Faruqee, R. R. (2003). The Impact Of Farm Credit In Pakistan. Agricultural Economics, 28(3), 197-213.

Kibrom, T. G. (2010). Determinants Of Successful Loan Repayment Performance Of Private Borrowers In Development Bank Of Ethiopia North Region. Mekelle University. 
Kim, H., \& Devaney, S. A. (2001). The Determinants Of Outstanding Balances Among Credit Card Revolvers. Journal Of Financial Counseling And Planning, 12(1), 67.

Makorere, R. F. (2014). Factors Affecting Loan Repayment Behaviour In Tanzania: Empirical Evidence From Dar Es Salaam And Morogoro Regions. International Journal Of Development And Sustainability, 3(3), 481492.

Mccrae, R. R., \& John, O. P. (1992). An Introduction To The Five-Factor Model And Its Applications. Journal Of Personality, 60(2), 175-215.

Munene, H. N., \& Guyo, S. H. (2013). Factors Influencing Loan Repayment Default In Micro-Finance Institutions: The Experience Of Imenti North District, Kenya. International Journal Of Applied, 3(3).

Murray, H. A. (1938). Explorations In Personality.

Nyhus, E. K., \& Webley, P. (2001). The Role Of Personality In Household Saving And Borrowing Behaviour. European Journal Of Personality, 15(S1), S85-S103.

Ogeisia, S. K., Musiega, D., \& Manase, G. W. IMPACT OF BORROWER CHARACTER ON LOAN REPAYMENT IN COMMERCIAL BANKS WITHIN KAKAMEGA TOWN.

Petersen, M. A. (1999). Banks And The Role Of Lending Relationships: Evidence From The US Experience. Rassegna Economica, 63(1), 37-61.

Rauf, S. A., \& Mahmood, T. (2009). Growth And Performance Of Microfinance In Pakistan. Pakistan Economic And Social Review, 99-122.

Rustichini, A., Deyoung, C. G., Anderson, J. C., \& Burks, S. V. (2012). Toward The Integration Of Personality Theory And Decision Theory In The Explanation Of Economic And Health Behavior. 
